\title{
Health related quality of life of chronic patients with immune system diseases: a pilot study
}

\author{
Qualidade de vida relacionada com a saúde de doentes crónicos com \\ patologias do sistema imune: estudo piloto \\ Calidad de vida relacionada con la salud de pacientes crónicos con enfermedades
}

del sistema inmune: estudio piloto

\section{Claudia Campos Ribeiro', Augusta Silveira", Isabel Silva"', Catarina Ribeiro"II, Juan Gestal' ${ }^{\mathrm{IV}}$, Carlos Vasconcelos ${ }^{\mathrm{v}}$}

\footnotetext{
' Universidade de Medicina Santiago de Compostela (Doutoranda). Santiago de Compostela, Espanha. Universidade Católica Portuguesa, Centro Hospitalar do Porto, Hospital Santo António. Porto, Portugal. "Universidade Fernando Pessoa, Instituto de Ciências Biomédicas Abel Salazar (Doutoranda). Porto, Portugal.

I" Universidade Fernando Pessoa. Porto, Portugal.

Iv Universidade de Medicina Santiago de Compostela, Servicio de Medicina Preventiva y Salud Pública. Santiago de Compostela, Espanha.

${ }^{v}$ Centro Hospitalar do Porto, Hospital Santo António, Unidade de Imunologia Clinica. Porto, Portugal.
}

Submissão: 03-01-2011 Aprovação: 17-07-2012

\section{ABSTRACT}

Health related quality of life (HRQL) and survival are two important outcome measures in chronic diseases. This study aimed to compared HRQL in patients with different chronic diseases of immune system and normative data from the general Portuguese Population. It was selected 103 out-patients, by convenience, to complete SF-36v2. The lowest scores were found among measures for general health (41.0), vitality (47.5), bodily pain (51.0), mental health (56.4); women, except for role-physical, and patients with auto-immune diseases have had the worse scores on all assessed dimension of subjective health, when compared with normative data. Highest scores were obtained in the following scales: physical functioning (69.1), social functioning (66.9), role-emotional (64.9). Living with chronic immune disease have impact on HRQL and it can be expected that the Portuguese version of SF-36v2 provide valid and reliable HRQL data.

Key words: SF-36v2; Quality of Life; Health related Quality of Life; Chronic Immune Diseases.

\section{RESUMO}

A qualidade de vida relacionada com a saúde (QVRS) e sobrevivência são dois desfechos importantes nas doenças crónicas. Este estudo objetivou comparar a QVRS de pacientes com diferentes patologias crónicas do sistema imune e com os dados normativos da população Portuguesa. Foram seleccionados 103 pacientes para a amostra por conveniência, para completar o SF-32v2. As pontuações mais baixas foram encontradas entre as medidas para a saúde geral $(41,0)$, vitalidade $(47,5)$, dor $(51,0)$ e saúde mental $(56,4)$; as mulheres, exceto na função física, e os doentes com doenças autoimunes obtiveram piores escores em todas as dimensões, quando comparados com os dados normativos. Os escores mais altos foram obtidos nas dimensões: função física $(69,1)$, funcionamento social $(66,9)$ e função emocional $(64,9)$. Viver com doenças crónicas imunológicas apresenta impacto sobre a QVRS e a versão Portuguesa do SF-36v2 fornece dados válidos e confiáveis na mensuração da QdV destes doentes.

Descritores: SF-36v2; Qualidade de Vida; Qualidade de Vida relacionada com a Saúde; Doenças Crónicas Imunes.

\section{RESUMEN}

Calidad de vida relacionada con la salud (CVRS) y la supervivencia son dos resultados importantes en las enfermedades crónicas. El objetivo de este estudio fue comparar la calidad de vida relacionada con la salud (CVRS) de los pacientes con diferentes patologías del sistema inmunológico y los datos normativos de la población portuguesa. 103 pacientes fueron seleccionados al acaso para completar el cuestionario SF-32v2. Las más bajas mensuras se encuentran entre las medidas de salud en general $(41,0)$, vitalidad $(47,5)$, dolor $(51,0)$ y salud mental $(56,4)$ que las mujeres en la función física y los pacientes con enfermedades autoinmunes también obtuvieron peores puntuaciones, en todas las dimensiones en comparación con los datos normativos. Las puntuaciones más altas se obtuvieron en las dimensiones: función física $(69,1)$, funcionamiento social $(66,9)$, función emocional $(64,9)$. Vivir con enfermedades crónicas inmunológicas ten un impacto en la CVRS y la versión portuguesa del cuestionario SF 36v2 aporta datos válidos y confiables para medir la CdV de estos pacientes.

Palabras clave: SF-36v2; Calidad de Vida; Calidad de Vida relacionada con la Salud; Enfermedades Inmunológicas Crónicas. 


\section{BACKGROUND}

A patient's well being is determined not only by his or her health status and response treatment, but also by other social and psychological dimensions. The identification of factors that determine quality of life (QoL) is important in order to better tailor health and social care services, and thereby improve the functioning and well being of people living with chronic pathologies of immune diseases.

In addition, the identification of potentially modifiable factors of QoL could help target people in need of additional services in order to improve $\mathrm{QoL}^{(1)}$. Besides physical and mental health-related factors, socio-demographic characteristics, such as age, gender, education, income and employment status, have found to be strongly associated with the QoL of people living with Human Immunodeficiency Virus (PLHIV) ${ }^{(2)}$ and auto-immune diseases (PLAD) like systemic lupus erythemato$\operatorname{sus}^{(3)}$, scleroderma ${ }^{(4)}$, rheumatoid arthritis ${ }^{(5)}$, Behçet's disease ${ }^{(6)}$ or Sjögren Syndrome ${ }^{(7)}$.

Chronic dysfunction of the immune system, like immunodeficiency and self-immunity, can affect multiple organ systems and lead to increased mortality. However, with more effective treatment ${ }^{(8,)}$, chronic long-term morbidity and relapse are now the most significant aspects of such diseases. Improved survival with continuing morbidity highlights the need for accurate assessment of patients suffering from these diseases and their response to therapy ${ }^{(9)}$. For chronic illnesses where there is no cure, it is important to establish that therapy really makes people feel better. Thus, survival per se is no longer perceived to be the only end point; the goal is to improve, restore, or preserve QoL.

In this sense, HRQL measurement represents a radical realignment between the objective and subjective elements of clinical medicine ${ }^{(10)}$. However, each domain of HRQL has many components, and there are an almost infinite number of states of health, all with differing qualities, and all quite independent of longevity ${ }^{(11)}$. Moreover, since expectations regarding health and the ability to cope with limitation and disability can greatly affect a person's perception of health and satisfaction with life, two persons with the same health status may have different qualities of life. Therefore, the construct can be defined in a number of ways, and a consensus of what the term means has not been reached. Thus a challenge for clinicians and researchers has been to know their patients' $\mathrm{QoL}^{(12)}$.

The purpose of this pilot study was to examine QoL among PLHIV, PLAD and norms excepted for Portuguese population and to assess the impact of socio-demographic like gender and age, and disease related variables like diagnosis on QoL in order to facilitate the development of treatment and decisions made.

\section{METHODS}

\section{Patient selection}

One hundred and three patients in the study were from Unidade de Imunologia Clinica - Hospital Santo António Centro Hospitalar do Porto. This unit is dedicated to treatment of patients with diagnosis of immune system diseases, like systemic autoimmune diseases and primary and secondary (HIV) immunodeficiency's. As a criterion for inclusion of patients it was considered the diagnosis: infection with HIV or autoimmune disease (arthritis rheumatoid, lupus, scleroderma, Behçet disease or Syndrome Sjögren). Exclusion criteria included patients under age 18 or incomplete medical record data.

\section{Procedure}

The survey was conducted from February 2009 to May 2009. The sample under study was selected by convenience. During medical consultation, some patients followed in this service were approached and invited to participate in this research. The patients were informed of our intention to conduct the study. All patients invited, have agreed to participate. Patients answered to the paper questionnaire package, including socio-demographic data and QoL items, after their informed consent and before going to their clinical consultation. The study was approved by Hospital Santo António - Centro Hospitalar do Porto Ethics in Health Committee.

\section{Variables}

The variables analyzed in this study were obtained from four thematic sets of questions: HRQL, constituted using the SF-36v2 and sets of socioeconomic, demographic and clinical characteristics.

\section{Independent variables}

The independent variables of this study were demographic, socioeconomic and clinical characteristics: gender (male or female), age $(<30,30-50,57-70$ and $>71)$, education (0-4, $5-12$ and $>12$ years), marital status (Married, Single, Widow, Other), employment status (employed, student, retired and unemployed) and immune system diseases.

\section{Dependent variables}

The HRQL was measured by the application of the Portuguese version of SF-36v2, adapted to the Portuguese population by Ferreira ${ }^{(13)}$. The SF-36v2 is an updated version of the SF-36 and has been updated to simplify the layout, wording and response formats to minimize cultural bias ${ }^{(14-15)}$.

The dependent variables were the scores of the SF-36v2 scales: Physical Functioning, Role Emotional, Role Physical, Bodily Pain, Social Functioning, Mental Health, Vitality and General Health. These subscales can be summarized into Physical Component Summary (PCS) and Mental Component Summary (MCS) scores. The subscales of PF, RP, and BP contribute to PCS; MH, RE, and SF contribute to MCS; while $\mathrm{SF}, \mathrm{VT}$, and GH contribute to both summary scores ${ }^{(15)}$. All scales are reported as T scores, which correspond to a mean of $50^{(14)}$. The scores scales can range from 0 to 100 , with higher scores reflecting better functioning or well-being. In addition, physical (PCS) and mental (MCS) component summary scores can be calculated from the SF-36v2 based on a population norm-based scoring function ${ }^{(15)}$.

\section{Internal consistency reliability of scales scores}

Different methods were used to assess reliability including internal consistency. The internal consistency was measured 
by Cronbach's alpha ${ }^{(16)}$ coefficients wish is a measure of the extent to which items in a questionnaire are homogeneous (correlated) in supporting the same concept. A Cronbach's $\alpha$ value of .70 or higher was generally considered to be sufficient to demonstrate internal consistency ${ }^{(16)}$.

\section{Data Management and Statistical analysis}

Descriptive analyses were performed for socio-demographic variables, clinical status and the health domains of SF$-36 v 2$. Descriptive statistics for SF-36v2 are given as mean, standard deviation (SD) and number of participants. SF-36v2 expected scores were calculated based on the normative data from the general Portuguese population aged 18-64 years that were randomly drawn from the Portuguese Population Register $(n=2459)^{(16)}$. Internal consistency reliability of multi-item scale was assessed by Cronbach's a coefficient ${ }^{(16)}$. A value of .70 or greater was considered as adequate for the purposes of group comparisons. All SF-36v2 scale scores were transformed linearly to a scale from 0 to 100 , with o and 100 representing the least and most favorable health outcomes respectively. Data were analyzed using SPSS version 16.0.

\section{RESULTS}

A total of 103 participants were interviewed: 66 women and 37 men, with a mean age of 45.28 years with a standard deviation 15.32. Regarding the marital status, $50.48 \%$ of the individuals are married, $20.38 \%$ are single, $8.73 \%$ are widow and $20.38 \%$ have other marital status. About 48 are employed and $72.80 \%$ had less than five years of schooling. According to the diagnosis, $70.87 \%$ had autoimmune disease and $29.13 \%$ was infected by HIV. Table 1 summarizes the main characteristics of the sample studied.

Scores of QoL were lowest in the following dimensions: general health (41.0), vitality (47.5), bodily pain (51.0) and mental health (56.4). Highest scores were obtained in the following scales: physical functioning (69.1), social functioning (66.9), role-emotional (64.9) (Table2).

Women obtained lower scores than men in all domains except for role-physical (Table3). The greatest difference between genders was found in the vitality, with a difference of 12.3 points between mean scores.

According the diagnoses revealed that PLAD obtained lower scores in all dimension than PLHIV (Table4). The greatest difference between PLAD and PLHIV was found in bodily pain with a difference of 21.6 points between mean scores.

\section{Comparisons with the expected scores of the general population}

Table 4 shows the SF-36v2 health status scores among patients with chronic immune diseases compared to the Portuguese norms scores. PLHIV and PLAD had worse crude scores for all dimensions of health compared with normative data.
Table 1 - Socio-demographic and clinical variables of the sample $(n=103)$.

\begin{tabular}{|c|c|c|}
\hline \multicolumn{3}{|c|}{$\begin{array}{l}\text { Sample characteristics according to demographic, } \\
\text { socioeconomic and clinical variables. }\end{array}$} \\
\hline & $\mathrm{N}$ & $\%$ \\
\hline \multicolumn{3}{|l|}{ GENDER } \\
\hline Female & 66 & 64.07 \\
\hline Male & 37 & 35.93 \\
\hline AGE X(SD) & $45,28(15,327)$ & \\
\hline$<30$ & 19 & 18.4 \\
\hline $30-50$ & 48 & 46.60 \\
\hline $51-70$ & 30 & 29.12 \\
\hline$>70$ & 6 & 5.82 \\
\hline \multicolumn{3}{|l|}{ EDUCATION YEARS } \\
\hline $0-4$ & 28 & 27.18 \\
\hline $5-12$ & 45 & 43.68 \\
\hline$>12$ & 30 & 29.12 \\
\hline \multicolumn{3}{|l|}{ MARITAL STATUS } \\
\hline Married & 52 & 50.48 \\
\hline Single & 21 & 20.38 \\
\hline Widow & 9 & 8.73 \\
\hline Other & 21 & 20.38 \\
\hline \multicolumn{3}{|l|}{ EMPLOYMENT STATUS } \\
\hline Employed & 48 & 46.60 \\
\hline Student & 9 & 8.73 \\
\hline Retired & 25 & 24.27 \\
\hline Unemployed & 21 & 20.38 \\
\hline \multicolumn{3}{|l|}{ DIAGNOSIS } \\
\hline PIHIV & 30 & 29.13 \\
\hline PLAD & 73 & 70.87 \\
\hline LENGTH OF DISEASE X (SD) & $7,01(6,935)$ & \\
\hline \multicolumn{3}{|l|}{ SYSTEMS/ ORGANS AFFECTED } \\
\hline Immunological & 103 & 100 \\
\hline Skin & 48 & $40,7 \%$ \\
\hline Osteoarticular & 32 & 27,1 \\
\hline Hematological & 10 & 8,5 \\
\hline Gastrointestinal & 9 & 7,6 \\
\hline Renal & 6 & 5,1 \\
\hline Pulmonary & 4 & 3,4 \\
\hline Cardiac & 4 & 3,4 \\
\hline Others & 5 & 4,2 \\
\hline
\end{tabular}

Table 2 - Mean scores of SF-36v2 scales total sample.

\begin{tabular}{lccccc}
\hline $\begin{array}{l}\text { SF-36V2 HEALTH } \\
\text { STATUS DOMAINS }\end{array}$ & $\begin{array}{c}\mathrm{n} \text { (Total } \\
\text { sample) }\end{array}$ & MEAN & SD & $95 \% \mathrm{Cl}$ & $\begin{array}{c}\text { Std. } \\
\text { ERROR }\end{array}$ \\
\hline PHYSICAL FUNCTIONING & 103 & 69.1 & 23.74 & $64.5-73.6$ & 2.30 \\
ROLE-PHYSICAL & 103 & 62.0 & 28.95 & $56.4-67.6$ & 2.81 \\
BODILY PAIN & 103 & 51.0 & 29.62 & $45.3-56.8$ & 2.87 \\
GENERAL HEALTH & 103 & 41.0 & 21.55 & $36.9-45.2$ & 2.09 \\
VITALITY & 103 & 47.5 & 24.97 & $42.7-52.3$ & 2.42 \\
ROLE-EMOTIONAL & 103 & 64.9 & 27.88 & $59.1-70.6$ & 2.89 \\
SOCIAL FUNCTIONING & 103 & 66.9 & 29.85 & $61.9-72.3$ & 2.70 \\
MENTAL HEALTH & 103 & 56.4 & 24.42 & $51.7-61.1$ & 2.37 \\
\hline
\end{tabular}


Table 3 - Mean scores SF-36v2 scales according to gender and diagnoses.

\begin{tabular}{|c|c|c|c|c|c|c|c|}
\hline \multirow{2}{*}{ SF-36v2 } & \multirow{2}{*}{ Variables } & \multirow{2}{*}{$N=103$} & \multirow{2}{*}{ Mean } & \multirow{2}{*}{ Std. Deviation } & \multicolumn{2}{|c|}{$95 \% \mathrm{Cl}$} & \multirow[t]{2}{*}{ Std Error } \\
\hline & & & & & Min & Máx & \\
\hline \multicolumn{8}{|c|}{ Gender } \\
\hline \multirow{2}{*}{ Physical Functioning } & Female & 66 & 68.516 & 23.86 & 62.78 & 74.24 & 2.87 \\
\hline & Male & 37 & 70.22 & 23.74 & 62.30 & 78.14 & 3.90 \\
\hline \multirow{2}{*}{ Physical Problem } & Female & 66 & 61.02 & 28.06 & 54.27 & 67.76 & 3.37 \\
\hline & Male & 37 & 64.02 & 30.84 & 53.73 & 74.30 & 5.07 \\
\hline \multirow{2}{*}{$\begin{array}{l}\text { Bodily } \\
\text { Pain }\end{array}$} & Female & 66 & 48.30 & 27.23 & 41.76 & 54.84 & 3.27 \\
\hline & Male & 37 & 56.29 & 33.40 & 45.15 & 67.43 & 5.49 \\
\hline \multirow{2}{*}{ General Health } & Female & 66 & 39.71 & 22.01 & 34.42 & 44.99 & 2.64 \\
\hline & Male & 37 & 43.67 & 20.71 & 36.77 & 50.58 & 3.40 \\
\hline \multirow{2}{*}{ Vitality } & Female & 66 & 43.29 & 24.14 & 37.49 & 49.09 & 2.90 \\
\hline & Male & 37 & 55.57 & 24.86 & 47.28 & 63.86 & 4.08 \\
\hline \multirow{2}{*}{ Social Function } & Female & 66 & 64.49 & 26.82 & 58.04 & 70.93 & 3.22 \\
\hline & Male & 37 & 71.62 & 29.55 & 61.76 & 81.47 & 4.85 \\
\hline \multirow{2}{*}{ Emotional Problems } & Female & 66 & 64.97 & 31.26 & 57.46 & 72.48 & 3.76 \\
\hline & Male & 37 & 64.86 & 27.43 & 55.71 & 74.01 & 4.51 \\
\hline \multirow{2}{*}{ Mental health } & Female & 66 & 52.89 & 24.79 & 46.94 & 58.85 & 2.98 \\
\hline & Male & 37 & 63.10 & 22.55 & 55.58 & 70.62 & 3.70 \\
\hline \multicolumn{8}{|c|}{ Diagnoses } \\
\hline \multirow{2}{*}{ Physical Function } & PLHIV & 30 & 76,074 & 23,214 & 67.40 & 84.74 & 4.23 \\
\hline & PLAD & 73 & 65,257 & 23,290 & 59.82 & 70.69 & 2.72 \\
\hline \multirow{2}{*}{ Physical Problems } & PLHIV & 30 & 69,375 & 29,285 & 58.43 & 80.31 & 5.34 \\
\hline & PLAD & 73 & 57,934 & 28,229 & 51.34 & 64.52 & 3.30 \\
\hline \multirow{2}{*}{$\begin{array}{l}\text { Bodily } \\
\text { Pain }\end{array}$} & PLHIV & 30 & 66,433 & 26,758 & 56.44 & 76.42 & 4.88 \\
\hline & PLAD & 73 & 44,863 & 28,745 & 38.15 & 44.29 & 3.36 \\
\hline \multirow{2}{*}{ General Health } & PLHIV & 30 & 46,667 & 19,007 & 39.56 & 53.76 & 3.47 \\
\hline & PLAD & 73 & 39,397 & 22,455 & 34.15 & 44.63 & 2.62 \\
\hline \multirow{2}{*}{ Vitality } & PLHIV & 30 & 56,667 & 23,439 & 47.91 & 65.41 & 4.27 \\
\hline & PLAD & 73 & 43,579 & 24,956 & 37.75 & 49.40 & 2.92 \\
\hline \multirow{2}{*}{ Social Function } & PLHIV & 30 & 70,833 & 28,868 & 70.83 & 60.05 & 5.27 \\
\hline & PLAD & 73 & 65,411 & 27,601 & 58.97 & 71.85 & 3.23 \\
\hline \multirow{2}{*}{ Emotional Problems } & PLHIV & 30 & 65,833 & 30,976 & 65.83 & 54.26 & 5.65 \\
\hline & PLAD & 73 & 64,041 & 29,784 & 57.09 & 70.99 & 3.48 \\
\hline \multirow{2}{*}{ Mental health } & PLHIV & 30 & 59,167 & 22,325 & 50.83 & 67.50 & 4.07 \\
\hline & PLAD & 73 & 55,480 & 25,224 & 49.59 & 61.36 & 2.95 \\
\hline
\end{tabular}

Table 4 - Health status patients with chronic disease versus Portuguese norms scores

\begin{tabular}{|c|c|c|c|c|c|c|}
\hline \multirow[b]{2}{*}{$\begin{array}{l}\text { SF-36v2 Health } \\
\text { status domains }\end{array}$} & \multicolumn{2}{|r|}{ MEAN } & \multicolumn{2}{|r|}{ SD } & \multicolumn{2}{|r|}{$95 \% \mathrm{Cl}$} \\
\hline & $\begin{array}{c}\mathrm{n} \\
\text { (Total sample) } \\
103\end{array}$ & $\begin{array}{c}\mathrm{n} \\
\text { (General population) } \\
2459\end{array}$ & $\begin{array}{c}\mathrm{n} \\
\text { (Total sample) }\end{array}$ & $\begin{array}{c}\mathrm{n} \\
\text { (General population) }\end{array}$ & $\begin{array}{c}\mathrm{n} \\
\text { (Total sample) }\end{array}$ & $\begin{array}{c}\mathrm{n} \\
\text { (General population) }\end{array}$ \\
\hline Physical Function & 69.1 & 75.2 & 23.7 & 26.7 & $64.5-73.6$ & $60.00-85.00$ \\
\hline Physical Problems & 62.0 & 71.2 & 28.9 & 25.7 & $56.4-67.6$ & $56.3-75.0$ \\
\hline $\begin{array}{l}\text { Bodily } \\
\text { Pain }\end{array}$ & 51.0 & 63.3 & 29.6 & 24.9 & $45.3-56.8$ & $42.0-62.0$ \\
\hline General Health & 41.0 & 55.8 & 21.5 & 18.8 & $36.9-45.2$ & $45.0-55.0$ \\
\hline Vitality & 47.5 & 58.4 & 24.9 & 25.6 & $42.7-52.3$ & $40.0-60.0$ \\
\hline Social Function & 64.9 & 74.9 & 27.8 & 22.8 & $59.1-70.6$ & $62.5-75.0$ \\
\hline Emotional Problems & 66.9 & 73.5 & 29.8 & 24.5 & $61.9-72.3$ & $58.3-75.0$ \\
\hline Mental Health & 56.4 & 64.0 & 24.4 & 22.8 & $51.7-61.1$ & $52.0-68.0$ \\
\hline
\end{tabular}

*The Portuguese norms SF-36v2 and dimensions' scores of health status perception from patients with chronic immune diseases: means and standard deviations. 
Table 5 - Cronbach's a for the SF-36v2.

\begin{tabular}{l|ccccc}
\hline & \multicolumn{4}{|c}{ Reliability } & Correlation \\
\hline Dimension & $\begin{array}{c}\text { Number } \\
\text { of items }\end{array}$ & $\begin{array}{c}\text { Split-half } \\
\text { reliability }\end{array}$ & $\begin{array}{c}\text { Cronbach's } \\
\text { alfa }\end{array}$ & $\begin{array}{c}\text { Correlations between } \\
\text { dimensions and } \\
\text { items inside }\end{array}$ & $\begin{array}{c}\text { Correlations between dimensions } \\
\text { and items outside }\end{array}$ \\
\hline Physical Function & 10 & .936 & .893 & $.497-.830$ & $.046-.575$ \\
Physical Problems & 4 & .938 & .907 & $.827-.928$ & $.177-.724$ \\
Bodily & 2 & .917 & .917 & $.950-.952$ & $.072-.571$ \\
Pain & 5 & .701 & .780 & $.601-.777$ & $.195-.521$ \\
General Health & 4 & .930 & .848 & $.791-.826$ & $.149-.596$ \\
Vitality & 2 & .777 & .777 & $.883-.907$ & $.153-.649$ \\
Social Function & 3 & .842 & .886 & $.854-.926$ & $.126-.702$ \\
Emotional Problems & 5 & .855 & .893 & $.805-.887$ & $.106-.650$ \\
Mental Health & 5 & &
\end{tabular}

\section{Internal consistency reliability}

Cronbach's Alpha was .944 at baseline and item correlation ranged from .940 to .949 (SF dimension with .777 and the BP dimension .917) (Table5). These data provide evidence of the internal consistency of the scale.

\section{DISCUSSION}

Quality of life is a study area that has attracted increasing interests over the past two decades and SF-36v2 has been used as an instrument for assessing QoL worldwide. Normative data have also been obtained in many countries. In Portugal, SF-36v2 has been used in a few surveys to assess the quality of life of general population and the population with special chronic diseases ${ }^{(16)}$. Summary scores can be used to minimize problems with multiple comparisons.

Poor (low) scores on the PCS indicate limitations in physical/role functions, bodily pain, and general health, while better (higher) scores suggest no physical limitations, disabilities, or decrements in well-being. In like manner, a low score on the MCS suggests frequent limitations in psychosocial health, emotional problems, and reduced vitality (a fatigue construct), while a high score indicates frequent positive affect and vitality, absence of psychological distress, and reduced or no limitations in daily social and role activities ${ }^{(15)}$.

In this present study among the eight dimensions assessed by the SF-36v2, the population studied in the present survey obtained worst scores in the scales general health, vitality, bodily pain and mental health. There were also differences in health status between the subgroups and the expected scores of the general population, and differences between the groups according to clinical diagnosis. PLAD had significantly reduced scores than PLHIV. This can be due to the nature of the diseases, were autoimmune diseases will have more manifestations of physical symptoms that are more prone to affect especially physical health domains, whereas having infected by HIV may cause more worries and distress because there might be more uncertainties around symptoms, management of disease, potentially affecting more psychological measures.
Analyzing HRQL according to gender, this study showed that women were in worse situation than men in all SF-36v2 scales except in role-physical. Similar results were found in other studies $^{(18-19)}$. The fact that women exhibit a worse self-assessed level of health may be attributed to the greater perception and knowledge that have regarding diseases and symptoms ${ }^{(20)}$. The role as a family health caregiver makes women dedicate more attention to the signs of diseases. Studies generally demonstrate a greater prevalence of reported illness and use of healthcare services among women in comparison to men ${ }^{(20)}$.

The demographic changes occurring in the country, with a growing number of patients with chronic illnesses, stressed the need to assess and to monitor different health dimensions in order to guide specific interventions ${ }^{(20)}$. Measures of HRQoL are especially required from the perspective of promoting active ageing that foresees the inclusion of the chronic patients in social contexts, with autonomy and independence in their activities, as well as actively contributing in community.

Croncbach's alpha was used to determine whether the items within the scaled questionnaires had the same degree of association in the mode of administration at the baseline assessment. The internal consistency reliability of the SF-36v2 scales was satisfactory. Our data demonstrate SF-36v2 can be used to assess HRQL in patients with different chronic immune diseases.

In addition, this study had limitations that should be noted. First our sample was relatively small. Second, the questionnaire required self-completion. This could be possibly had a negative effect on the response rate, particularly in illiterate individuals whose literacy rates tend to be lower. For last, compared diseases so different it unusually but the ultimate goal, will be in the future measured HRQL in practice daily routine in Unidade de Imunologia Clinica - Hospital Santo António Centro Hospitalar do Porto, responsible to consult patients with affections of immune system.

\section{CONCLUSION}

In conclusion, living with chronic immune diseases is most likely to health status vulnerability. In general, persons with 
chronic immune diseases perceive their current health; health outlook and resistance to illness to be lower than general population, and for these patients physical health and mental health can in addition limit and interfere with work or daily activities.

This data contributes to the input needed for planning health care service and intervention that address QoL improvement for PLHIV and PLAD. The availability of HR-QOL score immediately during the consultation could contribute to patient centered care, help to focus the patient-physician consultation, supporting the definition of therapeutic goals as well as the evaluation of their achievement, and provides standardized data, which can be compared intra- and inter- individually.

\section{BIBLIOGRAPHY}

1. McDonnell KA, Gielen AC, O'Campo P, Burke JG: Abuse, HIV status and health-related quality of life among a sample of HIV positive and HIV negative low income women. Qual Life Res 2005;14:945-57.

2. Murri R, Fantoni M, Del Borgo C, Visona R, Barracco A, Zambelli A, Testa L, Orchi N, Tozzi V, Bosco O, Wu AW: Determinants of health-related quality of life in HIV-infected patients. AIDS Care 2003; 15(4):581-90.

3. Panopalis P, Petri M, Manzi S, et al. The systemic lupus erythematosus tri-nation study: longitudinal changes in physical and mental well-being. Rheumatol 2005;44:751-5.

4. Danieli E, Paolo A, Lorenzo B, Cinquini M, Antonioli CM, Cavazzana I, Franceschini RC. Health-related quality of life measured be the Short Form 36 (S-36) in systemic sclerosis: correlations with indexes of disease activity and severity, disability, and depressive symptoms. Clin Rheumatol 2005;24:48-54

5. Strombeck B, Ekdahl C, Manthorpe R, Wikstrom I, Jacobsson LT. Health-related quality of life in primary Sjogren's syndrome, rheumatoid arthritis and fibromyalgia compared to normal population data using the SF-36. Scand J Rheumatol 2000;29:20-8.

6. Ertam I, Kitapcioglu G, Aksu K, Keser G, Ozaksar A, Elbi $\mathrm{H}$, Unal I, Alper S. Quality of life and its relation with disease severity in Behçet's disease. Clin Exp Rheumatol 2009;27(2 Suppl 53):S18-22.

7. Rostron J, Rogers S, Longman L, Kaney S, Field EA. Healthrelated quality of life in patients with Primary Sjogren's Syndrome and xerostomia: a comparative study. Gerontol 2002; 19:53-59.

8. Emery P. Systemic lupus erythematosus. In: Butler RC, Jayson MIV, editors. Collected reports on the rheumatic diseases. Arthritis Res Campaign 1998:87- 92.

9. Bacon PA, Moots RJ, Exley A, Luqmani R, Rasmussen N. VITAL (Vasculitis Integrated Assessment Log) assessment of vasculitis. Clin Exp Rheumatol 1995:13: 275-8.
10. Sullivan M. The new subjective medicine: taking the patient's point of view on health care and health. Soc Sci Med 2003;56:1595-604.

11. Testa MA, Simonson DC. Assesment of quality-of-life outcomes. N Engl J Med.1996;334:835-40.

12. Okamoto $T$, Shimozuma $K$, Katsumata $N$, Koike $M$, Hisashige $A$, et al. Measuring quality of life in patients with breast cancer: a systematic review of reliable and valid instruments available in Japan. Breast Cancer 2003; 10:204-13.

13. Ferreira, P. Criação da versão portuguesa do MOS SF-36 Parte I- adaptação cultural e linguística. Acta Med Port 2000;13:55-63.

14. Hawthorne G, Osborne RH, Taylor A, Sansoni J. The SF36 Version 2: critical analyses of population weights, scoring algorithms and population norms. Qual Life Res 2007; 16:661-73.

15. Ware JE, Kosinski M, Dewey JE. How to score version 2 of the SF- $3^{6 \oplus}$ health survey (standard and acute forms). Lincoln: QualityMetric Incorporated; 2002.

16. Cronbach, L. J. Essentials Of Psychological Testing. New York: Harper Collins Publishers;1990.

17. Ferreira P.L., Santana, P. Percepção de estado de saúde e de qualidade de vida da população activa : contributo para a definição de normas portuguesas. Rev Port Saúde Pública 2003;21:15-30.

18. Ribeiro C. Qualidade de Vida dos doentes do Serviço de Imunologia Clínica do Centro Hospitalar do Porto, Hospital Geral de Santo António. In: Trabalho de Investigação Tutelado; 2008.

19. Dachs JNW, Santos APR. Auto-avaliação do estado de saúde no Brasil: análise dos dados da PNAD/2003. Ciênc Saúde Coletiva 2006;11:887-94.

20. Barros MBA, César CLG, Carandina L, Torre GD. Desigualdades sociais na prevalência de doenças crônicas no Brasil, PNAD-2003. Ciênc Saúde Coletiva 2006;11:911-26. 